\title{
Aggressive Herpes Zoster in Young Patients With Multiple Sclerosis Under Dimethyl Fumarate
}

\section{Significance of $\mathrm{CD}^{+}$and Natural Killer Cells}

Maria C. Anagnostouli, MD, Georgios Velonakis, MD, and Marinos C. Dalakas, MD, FAAN

Neurol Neuroimmunol Neuroinflamm 2021;8:e1017. doi:10.1212/NXI.0000000000001017

\author{
Correspondence \\ Prof. Anagnostouli \\ managnost@med.uoa.gr
}

Dimethyl fumarate (DMF), approved for relapsing-remitting multiple sclerosis (RRMS), exerts immune-mediated mechanisms crucial for $\mathrm{T}$-cell survival and migration, preferentially reducing $\mathrm{CD}^{+}{ }^{\mathrm{T}}$ cells. ${ }^{1}$ Although baseline absolute lymphocyte count (ALC) is considered the most critical predictor of developing lymphopenia, ${ }^{2}$ it was recently concluded that lymphocyte subset monitoring is not required for safety vigilance because $\mathrm{T}$-cell subset reduction does not increase risks for serious infections. ${ }^{3}$

We present 2 young patients with RRMS, under DMF treatment, negative for HIV and SARSCoV-2 (by RT-PCR in nasal swab) and with normal follow-up white blood cell (WBC)/ALC counts, who developed severe herpes zoster (HZ) infection with normal ALC but low CD8 ${ }^{+}$ and high CD56 $6^{\text {bright }}$ natural killer (NK) cells, and discuss the potential significance of T-cell immunophenotyping in $\mathrm{HZ}$ manifestation.

\section{Patient 1}

A 23-year-old woman was seen at age 16 years with acute cerebellar ataxia and trigeminal neuralgia. MRI showed nonenhancing T2-hyperintense periventricular and subtentorial lesions and CSF oligoclonal bands. Anti-AQP4 and anti-MOG antibodies were negative. After 6 months, new T2-hyperintense, enhancing, periventricular lesions developed and was started on interferon beta-1a with excellent response. Because of new enhancing cervical and thoracic demyelinating MRI lesions, she was started on DMF $240 \mathrm{mg}$ BID 2 years ago. In March, during the first peak of COVID-19, she presented with an aggressive, blistering rash extending from the right side of back to the chest (figure), typical of $\mathrm{HZ}$ with positive anti-varicella-zoster virus (VZV) antibodies. She reported chickenpox in childhood. DMF was discontinued, and 1-week treatment with brivudine (bromovinyldeoxyuridine) began followed by valaciclovir 1,000 mg TID for 20 days, tapered to $500 \mathrm{mg}$ daily. Her WBC and ALC counts were normal but had low $\mathrm{CD}^{+}$, very low $\mathrm{CD} 8^{+}$, lownormal $\mathrm{CD}^{+}{ }^{+} \mathrm{T}$ cells, and very high NK cells (table). After 2 months, the rash improved. Repeated MRI of the brain and cervical spine was stable. She was started on glatiramer acetate $40 \mathrm{mg} 3$ times/wk. After 3 months, $\mathrm{CD}^{+}, \mathrm{CD}^{+}$, and $\mathrm{CD} 8^{+} \mathrm{T}$ subsets remain still low (table). Although SARS-CoV-2-PCR was negative and always asymptomatic, she had antibodies to SARS$\mathrm{CoV}$-2-spike protein when tested 10 months after the $\mathrm{HZ}$ manifestation.

\section{Patient 2}

A 42-year-old man was admitted at age 28 years, with acute right arm numbness and dysuria. $\mathrm{He}$ had 2 other acute episodes 2 years earlier. MRI revealed multiple T2-hyperintense 

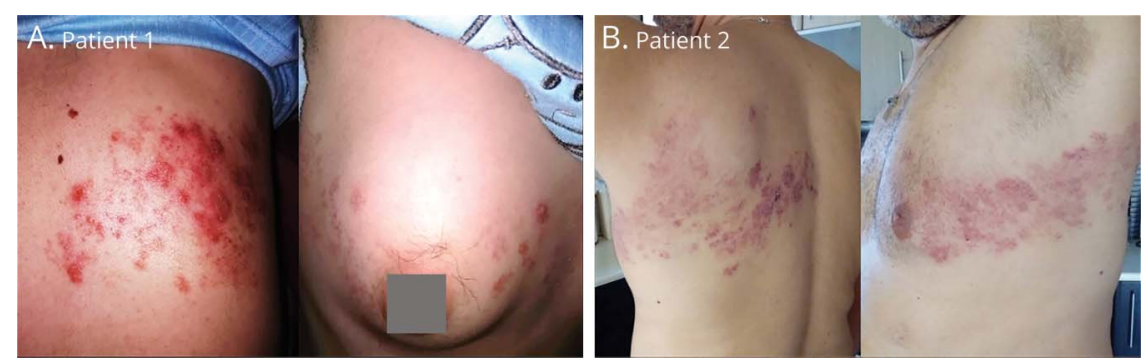

Extensive, blistering, herpes zoster $(\mathrm{HZ})$ rash extending from the right back to the anterior chest in (A) patient 1 and from the left back to the anterior chest in (B) patient 2.

periventricular, subcortical, and cervical lesions. He was given glatiramer acetate but because of 2 subsequent relapses was started on DMF $240 \mathrm{mg}$ BID 2 years ago. In October, during the COVID-19 peak, he developed an aggressive blistering rash, extending from his left back to the chest, typical of $\mathrm{HZ}$ with positive anti-VZV antibodies (figure). DMF was discontinued and was treated with 2-week brivudine followed by valaciclovir 1,000 mg TID for 30 days, tapered to $500 \mathrm{mg}$ daily. WBC and ALC were slightly below normal (grade-1 lymphocytopenia), but immunophenotyping showed low $\mathrm{CD} 3$, very low $\mathrm{CD} 8^{+}$, and very high NK cells with increased $\mathrm{CD}^{+}$and $\mathrm{CD} 19^{+} \mathrm{T}$ cells (table). After 1 month, the rash improved, but his $\mathrm{CD}^{+}$and $\mathrm{CD} 8$ - $\mathrm{T}$ cells remain low and $\mathrm{NK}$ cells high (table). MRI showed a new enhancing demyelinating cervical lesion, treated with corticosteroids. He was SARS-CoV-2-antibody-negative.

\section{Discussion}

VZV is a lymphotropic virus, which in immunosuppressed patients can be reactivated leading to $\mathrm{HZ}$ infection. Our patients are probably the first young, not immunodeficient patients with normal ALC to manifest severe HZ while on DMF, without any new CNS-clinical signs to warrant CSF examination. The study of their T-cell immunophenotyping at onset and after the infection revealed low CD8+ $\mathrm{T}$ cells and increased CD56 $6^{\text {bright }}$ $\mathrm{NK}$ cells that may be implicated in extensive $\mathrm{HZ}$ manifestation.

VZV acts on immune cells through cell-surface proteins, like programmed cell death protein 1 (PD-1), eliciting an immunoinhibitory function and reducing T-cell activation and cytokine secretion. DMF causes reduction of CD8+ T-cells, and CD8-cell depletion is associated with increased VZV reactivation, ${ }^{4,5}$ but whether in both our patients, the noted $\mathrm{CD} 8+\mathrm{T}$-cell reduction was the only culprit is unclear.

DMF also upregulates CD56 $6^{\text {bright }} \mathrm{NK}$ cells, which, in turn, inhibits $\mathrm{CD}^{+}$and $\mathrm{CD} 8^{+} \mathrm{IFN} \gamma$-producing $\mathrm{T}$-cell populations, promoting an anti-inflammatory state and enhancing its beneficial effects in DMF-treated patients. ${ }^{6} \mathrm{VZV}$ can however cause a productive infection of human $\mathrm{CD} 56^{\text {bright }} \mathrm{NK}$ cells and upregulates surface expression of chemokine receptors associated with trafficking to the skin where highly infectious lesions develop. ${ }^{7}$ The high number of CD56 $6^{\text {bright }} \mathrm{NK}$ cells noted in both our patients at the onset of skin rash might have facilitated the spread of VZV to the skin, producing such aggressive lesions unusual for young nonimmunosuppressed patients, requiring 6 weeks of antiviral therapy before resolution of skin lesions began. It is likely that the low $\mathrm{CD} 8^{+}$cells triggered $\mathrm{HZ}$ reactivation, but the presence of increased NK

Table Lymphocyte Immunophenotyping at the Time of HZ Onset and at Follow-up Periods, 3 Months Later for Patient 1 and 1 Month for Patient 2

\begin{tabular}{|c|c|c|c|c|c|c|c|c|}
\hline & & WBC & ALC & $\mathrm{CD}^{+}$ & $\mathrm{CD3}^{+} \mathrm{CD}^{+}$ & $\mathrm{CD}^{+} \mathrm{CD}^{+}$ & $\mathrm{CD} 19^{+}$ & NK \\
\hline \multirow[t]{3}{*}{ Patient 1} & Onset of $\mathrm{HZ}$ & 5,600 & 1,800 & $56.0 \% ; 1,000 *$ & $41.9 \% ; 734$ & $13.1 \% ; 230 *$ & $12.9 \% ; 235$ & $28.7 \% ; 523 *$ \\
\hline & After 3 mo & 4,500 & 1,700 & $61.1 \% ; 944^{*}$ & $45.6 \% ; 664$ & $13.8 \% ; 201$ * & $10.4 \% ; 170$ & $26.3 \% ; 428^{*}$ \\
\hline & Normal range laboratory 1 & $>4,000$ & $>1,000$ & $69 \%-81 \% ;>1,500$ & $40 \%-55 \%$ & $22 \%-30 \% ;>342$ & $7 \%-18 \%$ & $6 \%-15 \% ;<350$ \\
\hline \multirow[t]{3}{*}{ Patient 2} & Onset of $\mathrm{HZ}$ & $3,160 *$ & $929^{*}$ & $41.4 \% ; 385^{*}$ & $75.5 \% ; 290 *$ & $18.3 \% ; 70 *$ & $22.2 \% ; 206^{*}$ & $33.8 \% ; 314^{*}$ \\
\hline & After 1 mo & 7,460 & 1,634 & $46.4 \% ; 758^{*}$ & $73 \% ; 553 *$ & $22.6 \% ; 171^{*}$ & $30 \% ; 490 *$ & $22.1 \% ; 361^{*}$ \\
\hline & Normal range laboratory 2 & $>3,700$ & $>1,000$ & $75 \%-85 \% ;>1,000$ & $53 \%-65 \%$ & $24-41 ;>250$ & $3 \%-18 \%$ & $<18 \% ;<180$ \\
\hline
\end{tabular}

Abbreviations: ALC = absolute lymphocyte count; $\mathrm{HZ}=$ herpes zoster, >lower limit of normal, <upper limit of normal; WBC = white blood cell. The low $\mathrm{CD}^{+} \mathrm{CD}^{+}$cells and high NK cells are marked with an asterisk, providing the $\%$ and the total cell counts. The immunophenotyping was performed in 2 different laboratories (patient 1, laboratory 1; patient 2, laboratory 2), with different normal range; the cell percentage (\%) is therefore representative. 
cells facilitated such an extensive manifestation. Our cases highlight that $\mathrm{T}$-cell subset monitoring may still have a role during DMF therapy and that the combination of low CD8/ high NK requires attention. Although rare, the cases raise the question of pharmacovigilance and consideration for VZV vaccination in certain DMF-receiving patients.

\section{Study Funding}

The authors report no targeted funding.

\section{Disclosure}

The authors report no disclosures relevant to the manuscript. Go to Neurology.org/NN for full disclosures.

\section{Publication History}

Received by Neurology: Neuroimmunology \& Neuroinflammation January 2, 2021. Accepted in final form March 22, 2021.

\section{Appendix Authors}

\begin{tabular}{lll}
\hline Name & Location & Contribution \\
\hline $\begin{array}{l}\text { Maria C. } \\
\text { Mnagnostouli, }\end{array}$ & $\begin{array}{l}\text { National and Kapodistrian } \\
\text { University of Athens, } \\
\text { Athens, Greece }\end{array}$ & $\begin{array}{l}\text { Design or conceptualization } \\
\text { of the study, major role in the } \\
\text { acquisition of data, analysis } \\
\text { or interpretation of the data, } \\
\text { and drafting or revising the } \\
\text { article for intellectual } \\
\text { content }\end{array}$ \\
& \\
&
\end{tabular}

Appendix (continued)

\begin{tabular}{|c|c|c|}
\hline Name & Location & Contribution \\
\hline $\begin{array}{l}\text { Georgios } \\
\text { Velonakis, MD }\end{array}$ & $\begin{array}{l}\text { National and Kapodistrian } \\
\text { University of Athens, } \\
\text { Greece }\end{array}$ & $\begin{array}{l}\text { Major role in the acquisition } \\
\text { of data and drafting or } \\
\text { revising the article for } \\
\text { intellectual content }\end{array}$ \\
\hline $\begin{array}{l}\text { Marinos C. } \\
\text { Dalakas, MD, } \\
\text { FAAN }\end{array}$ & $\begin{array}{l}\text { National and Kapodistrian } \\
\text { University of Athens, } \\
\text { Greece; Thomas Jefferson } \\
\text { University, Philadelphia, PA }\end{array}$ & $\begin{array}{l}\text { Major role in the acquisition } \\
\text { of data, analysis or } \\
\text { interpretation of the data, } \\
\text { and drafting or revising the } \\
\text { article for intellectual } \\
\text { content }\end{array}$ \\
\hline
\end{tabular}

\section{References}

1. Spencer MC, Crabtree-Hartman EC, Lehmann-Horn K, Cree B, Zamvil SS. Reduction of CD8+ T lymphocytes in multiple sclerosis patients treated with dimethyl fumarate. Neurol Neuroimmunol Neuroinflamm. 2015;2(3):e76.

2. de la Maza SS, Medina S, Villarrubia N, et al. Factors associated with dimethyl fumarate-induced lymphopenia. J Neurol Sci. 2019;398:4-8.

3. Mehta D, Miller C, Arnold DL, et al. Effect of dimethyl fumarate on lymphocytes in RRMS: implications for clinical practice. Neurology. 2019;92(15):e1724-e1738.

4. Jones D, Como CN, Jing L, et al. Varicella zoster virus productively infects human peripheral blood mononuclear cells to modulate expression of immunoinhibitory proteins and blocking PD-L1 enhances virus specific CD8+ T cell effector function. PLoS Pathog. 2019;15(3):e1007650.

5. Weinberg A, Levin MJ. VZV T cell-mediated immunity. Curr Top Microbiol Immunol. 2010;342:341-357.

6. Al-Ani M, Elemam NM, Hundt JE, Maghazachi AA. Drugs for multiple sclerosis activate natural killer cells: do they protect against COVID-19 infection? Infect Drug Resist. 2020;13:3243-3254.

7. Campbell TM, McSharry BP, Steain M, Ashhurst TM, Slobedman B, Abendroth A. Varicella zoster virus productively infects human natural killer cells and manipulates phenotype. PLoS Pathog. 2018;14(4):e1006999. 


\title{
Neurology \\ Neuroimmunology \& Neuroinflammation
}

\author{
Aggressive Herpes Zoster in Young Patients With Multiple Sclerosis Under Dimethyl \\ Fumarate: Significance of CD8+ and Natural Killer Cells \\ Maria C. Anagnostouli, Georgios Velonakis and Marinos C. Dalakas \\ Neurol Neuroimmunol Neuroinflamm 2021;8; \\ DOI 10.1212/NXI.0000000000001017
}

This information is current as of May 28, 2021

Updated Information \&

Services

References

Subspecialty Collections

Permissions \& Licensing

Reprints including high resolution figures, can be found at:

http://nn.neurology.org/content/8/4/e1017.full.html

This article cites 7 articles, 1 of which you can access for free at: http://nn.neurology.org/content/8/4/e1017.full.html\#\#ref-list-1

This article, along with others on similar topics, appears in the following collection(s):

Multiple sclerosis

http://nn.neurology.org//cgi/collection/multiple_sclerosis

Information about reproducing this article in parts (figures,tables) or in its entirety can be found online at:

http://nn.neurology.org/misc/about.xhtml\#permissions

Information about ordering reprints can be found online: http://nn.neurology.org/misc/addir.xhtml\#reprintsus

Neurol Neuroimmunol Neuroinflamm is an official journal of the American Academy of Neurology.

Published since April 2014, it is an open-access, online-only, continuous publication journal. Copyright

Copyright (C) 2021 The Author(s). Published by Wolters Kluwer Health, Inc. on behalf of the American

Academy of Neurology.. All rights reserved. Online ISSN: 2332-7812.

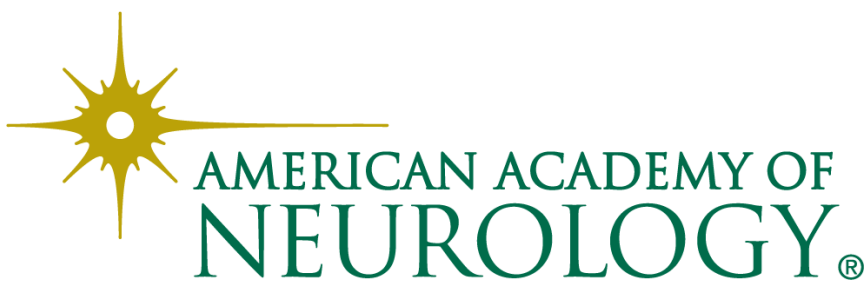

